\title{
Poliomyelitis in the City of Córdoba: Morbidity, Knowledge and the Research Performed by a Medical Elite in Argentina's Interior, 1943-1953
}

\author{
Adrián Carbonetti, Lila Aizenberg and \\ María Laura Rodríguez
}

\section{Introduction}

The complex problems presented by the production of medical knowledge in Argentina during the middle decades of the twentieth

1 century have been sidestepped by the nation's historiographers. ${ }^{1}$ Some studies begin their examination of these questions by describing the situation in Buenos Aires and focusing on its medical elite. Others describe and quantify the medical community's familiarity with this disease, or the lack thereof, during this time period. ${ }^{2}$ The lack of interest in the medical outlooks and scientific perspectives of Argentina's foremost doctors as they related to polio's symptoms, origin, causes and development has been linked to a narrative which describes "victories" as "rare" in the fight against poliomyelitis. While this article acknowledges that this undertaking is exploratory in nature and seeks to put forth its own questions and hypotheses,

1 The aftereffects suffered by children seriously affected by infantile paralysis, which include physical defects in their extremities and in their cores caused by irreparable damage to their neuromuscal systems - have been the subject of important studies. These interrogated how - and at what speed - the scientific community and Argentine society, represented here by federal institutions and others operating at a local level in the city of Buenos Aires, shaped their responses to this disease over the long term. D. Testa. "Poliomielitis: La herencia maldita y la esperanza de la rehabilitación. La Epidemia de 1956 en la Ciudad de Buenos Aires", Intersticios. Vol. 5 (2011). pp. 299-213 C. Ferrante. "Rengueando el estigma: Modos de ser, pensar y sentir (se) discapacitado construidos desde la práctica deportiva adaptada", RBSE, 9(27) (2010). pp. 909-1902.

2 K. Ramaciotti. Las politicas sanitarias del primer peronismo: ideas, tensiones $y$ prácticas. Thesis defended at the Facultad de Ciencias Sociales de la Universidad de Buenos Aires, (Buenos Aires, 2008). 
it rejects interpretations that seek only to collect, organize, and classify "scientific successes." Nor is it interested in reconstructing "errors" and "omissions" in order to label them scientific detours. ${ }^{3}$ With this in mind, we aim to rescue a universe of scientific production whose results were published locally by the foremost members of the medical profession in the province of Córdoba. We will do this by analyzing medical articles published in the Revista Médica de Córdoba and the Revista de la Universidad Nacional de Córdoba that examine Argentina's fatal polio cases at various points in time between the years 1943 and 1952. Because we understand that scientific progress can also be said to possess its own epidemiological and historic characteristics, this article will interrogate the links between medical research and the particularities of local morality rates. Our article will interrogate the connections between local medical science and knowledge produced in leading European countries, particularly in Sweden, and the United States. It will consider the kind of articles that were published in Córdoba, the sort of research was conducted there, and the link between knowledge produced elsewhere and local variables associated with the development of poliomyelitis. It should be understood that the receptive attitude displayed by members of the local medical community in Córdoba is closely linked to the sporadic appearance of fatal polio cases in the region from 1943 to 1952: the yearly totals of deaths attributed to this condition varied from year to year until the outbreak of an epidemic in 1952. This article will also comment on the city's experience with massive immunization, both with the Salk vaccine, which contained killed viruses, and with the more efficient Sabin vaccine of 1963, both of which were, of course, named for eminent American scientists whose discoveries led to the initiation of the controlled phase of this disease epidemic. ${ }^{4}$ However, this article will not lose sight of the fact that although the biomedical science developed in Argentina was, from the nation's founding, influenced by European scientists and European scientific discoveries, the processes by which this knowledge was received cannot be considered static. ${ }^{5}$ Our reading of these events holds that, along with the production dynamic of knowledge relating to poliomyelitis, other processes for the acquisition of knowledge were also emerging at this time at the local level. These processes are noteworthy because they involved investigative

3 S.Caponni. "Epistemología, Historia de las Ciencias y Saber médico", Episteme, v. 11, Nro. 23, (2006) p. 59.

4 D. Testa. "Poliomielitis: La herencia maldita y la esperanza de la rehabilitación. La Epidemia de 1956 en la Ciudad de Buenos Aires", Intersticios: Revista Sociológica de Pensamiento Crítico. Vol. 5 (2011), p. 309.

5 H. Vessuri "El crecimiento de una comunidad científica en argentina", Cad.Hist.Fil.Ci., Serie 3, V 5, (1995), p. 174. 
strategies that raised questions about a number of social issues, including some related to mortality, in an environment that would prove important to the study and development of medical science.

\section{The City of Córdoba: The State, Medicine, and Poliomyelitis}

The city of Córdoba, which is the capital of the province that bears the same name, is located in the northeast corner of Argentina's lowland coastal region. Throughout its history, the city has served as a nerve center and a communications hub connecting the country's coastal provinces to its northern and northeastern regions. Córdoba had been an indispensable center for commerce originating in Argentina's northern and central provinces during the colonial era and the early days of the Argentine republic, but when Argentina's coastal lowlands became a major producer of raw materials and participant in the international markets that traded them during the closing decades of the $19^{\text {th }}$ century, the city became better established in this role. At the same time, encroachment upon desert lands belonging to native tribes and the growth of transatlantic immigration transformed the city into an administrative center with dominion over a wide swath of southern Córdoba province, whose growth was likewise spurred by these phenomena. Taken together, these factors lent the city a rare dynamism: the city and its structures underwent a rapid modernization. ${ }^{6}$

When the city underwent a remarkable period of growth during the middle decades of the twentieth century, this state of affairs shifted, but, in some ways, became more firmly entrenched. In demographic terms, the population of the city of Córdoba nearly doubled during the period described in our study. According to official estimates, the city's population grew from 296,310 in 1944 to 420,531 in $1951 .^{7}$ This population growth was matched by record growth in the area's production capacity. According to Dadone, macroeconomic values recorded after 1950, such as those relating to the production of value-added products, show that the process of industrialization

6 W. Ansaldi. Industria y urbanización, Córdoba, 1880-1913, Universidad Nacional de Córdoba, Mimeo, (Córdoba, 1977), pp. 469-477.

7 Report of the Dirección General de Estadística Censos e Investigación, Ministerio de Hacienda, Economía y Previsión Social de la Provincia de Córdoba, Quinquenio 1944-1948. Published in 1953. Report of the Dirección General de Estadística Censos e Investigación, Ministerio de Hacienda, Economía y Previsión Social de la Provincia de Córdoba, 1949-1951. Published in 1953. 
was advancing "faster than the national rate" and more independently "as compared to the rest of the country's other large industrial centers."

Córdoba's long-term development was not, however, accompanied by the formulation of concrete responses to illnesses, particularly poliomyelitis. The condition of its public health system was defined by the relative absence of state intervention, though this might, of course, be attributed to an underdeveloped sanitation system and a general lack of understanding of the disease under discussion. As for sanitation policies, we have evidence of only a few actions carried out by the federal government after the beginning of the epidemic. As in 1946, these were typically control and prevention measures, such as cordons sanitaire, the disinfection and fumigation of stores, homes, schools, theaters, moviehouses, and the sewer system, the incineration of any wastes or domestic items that might carry infection, and the demolition of houses. That year also marked the first time that Argentine poliomyelitis patients were treated with streptomycin and sulphonamides.'

The resources available in Córdoba to fight poliomyelitis during the time period described in this report were limited to the Infantile Paralysis Section of the Hospital de Niños, which was, at the time, the only institution in the entire province dedicated to treating the disease. ${ }^{10}$ Relatively underequipped for this task, it focused its activities on alleviating the effects that the disease left in its wake. It should be noted that during the time period described by this study, which corresponds broadly to Argentina's era of Peronist rule (1946-1955), no significant improvements to the situation described herein were to take place.

During the time period described in this report, institutions in Córdoba devoted to medical science experienced significant development and carried out a significant amount of specialized research, a fact which provides a stark contrast to the state of affairs described above. Córdoba began to play a significant role in medical affairs during the latter part of the nineteenth century, a period which saw the founding and subsequent growth of the School of Medical Sciences at the Universidad Nacional de Córdoba. The founding of this institution goes beyond mere anecdote: it was the first center

8 This is in line with "(...) the type of industries that make up the bulk of the activity in this sector is more dynamic [in the local case]. A .Dadone. "Cien de la industrialización en Córdoba 1873-1973”, Revista de Economía Banco de la provincia de Córdoba, n 24, (1974). p. 155

9 K. Ramaciotti. Las politicas sanitarias del primer peronismo: ideas, tensiones y prácticas. Thesis defended at the Facultad de Ciencias Sociales de la Universidad de Buenos Aires, (Buenos Aires, 2008). p. 191.

10 L.A. Lezama "La Parálisis infantil en la ciudad de Córdoba", Revista de la Facultad de Ciencias Médicas de la Universidad Nacional de Córdoba, Año XII, JulioSeptiembre Nro. 3, (1954). p. 293. 
for medical instruction of its kind to be founded in Argentina's interior. Furthermore, the school served as both an important research center and a point of interaction for the region's medical professionals and medical scientists. ${ }^{11,12}$ The medical professionals that gathered there, who could be considered members of an elite, were both interested in and inspired by the idea that science could be advanced through the accumulation of medical knowledge. At no point was this more evident than when a few noted teaching doctors founded La Revista del Círculo Médico de Córdoba during the first decade of the twentieth century in the hopes of advancing both their profession and science itself. ${ }^{13}$ Their aspirations' influence on the activities of Córdoba's doctors would become even more pronounced during the nineteen thirties, when the journal gained prominence in the local medical publishing field and was incorporated into the Universidad Nacional de Córdoba. ${ }^{14}$ In 1943, another periodical, La Revista de la Facultad de Medicina de Córdoba appeared. Both of these publications served as the "powerhouses" for an effort to increase the visibility and influence of Córdoba's best medical professionals in the field of Argentine medicine by opening up spaces for medical research and debate.

It was in this context that Córdoba's first polio epidemic occurred. While poliomyelitis was not unknown in the city, it had, by 1943 , become endemic, and several locations in the province's interior had suffered epidemics of the disease, most notably Cruz del Eje, which is located in the province's northeast. A consistent rise in fatal cases attracted the concern of Córdoba's doctors, who initiated projects to better understand every aspect of the disease, including its nosological, epidemiological, clinical, and therapeutic character. This study will address the perspectives taken by the studies and scientific work produced by individuals and institutions in the city of Córdoba and will examine the issues they raise. It will focus on the time elapsed between the polio epidemic that Córdoba suffered in 1943 and the epidemic that broke out in the city in 1952, which was, in terms of fatalities, the more serious of the

11 Besides the Escuela de Medicina de la Universidad de Buenos Aires, the Facultad de Medicina de Córdoba, which was founded in 1878, was, during this period, the only institution in the country that trained doctors. Its graduates usually went on to settle in various parts of the country's interior. M.L. Rodriguez. "Perspectivas en torno a la consolidación de la elite médica de Córdoba. Epidemias y Estado, 1878-1923". Undergraduate thesis, Facultad de Historia, Universidad Nacional de Córdoba, (Córdoba. 2006). p. 87.

12 M.L. Rodríguez. La medicalización de la ciudad de Córdoba en tiempos epidémicos: conceptos, saberes e intervenciones 1878-1927. Editorial de la Municipalidad de Córdoba, (Córdoba , 2011). p. 56.

13 Revista Circulo Médico de Córdoba, Enero y Febrero, Año VIII, Nro. 3. (1920), p. 50.

14 Revista Circulo Médico de Córdoba, Abril y Mayo, Año XVI, Nro. 1, (1928), p. 60. 
two. It will examine articles written by both doctors and teachers at the Facultad de Ciencias Médicas of the Universidad Nacional de Córdoba and analyze both their authors' perspectives on the pathology of this disease and the research practices they employed while investigating it.

\section{Poliomyelitis According to Córdoba's Doctors: A Reconstruction of Knowledge}

Rosenberg makes the observation that a disease does not exist until society has agreed on its name, its symptoms, and its forms of treatment. This is to say that disease, from a social perspective, is a social and historical construction produced by science and society. ${ }^{15}$ We must also add something else to this statement: the fact that disease is constructed historically does not, in itself, determine the specific concerns of medical science or the way that its investigations into these concerns develop. This appears to be the case with poliomyelitis in Córdoba: it is worth remembering that the city had, since the end of the nineteenth century, been home to a university with a medical school that carried out basic research. This constitutes a very significant track record, and it also bears mentioning that, beginning in 1915, when Salversan proved impossible to import, the Facultad de Medicina de Córdoba made continual efforts to develop an alternative cure for syphilis. Dr. Aparicio, referring to this issue, noted that, "the earliest Salversan trials date to 1913 in regards to syphilis in the nervous system. However, in 1915, we began trials using intravenous mercury cyanide. ${ }^{16}$ It is particularly illuminating to refer to local studies on contagious diseases such as tuberculosis, whose study inspired the founding of a professorship and an institute devoted to the advancement of phthisiology in the early nineteen thirties. ${ }^{17}$ Generally speaking, a review of the subjects discussed in the only medical journal published in the region during that era, La Revista Médica de Córdoba, reveals a marked interest in the

15 C.E Rosenberg. "Disease in History: Frames and Framers". The Milkbank Quarterly, 67, Suppl. 1, (1989).p. 1.

16 M. L Rodriguez. "Perspectivas en torno a la consolidación de la elite médica de Córdoba. Epidemias y Estado, 1878-1923". Undergraduate thesis, Facultad de Historia, Universidad Nacional de Córdoba (Córdoba, 2006). p. 35.

17 A.. Carbonetti. "El sistema sanitario en la provincia de Córdoba, 1880-1926", Dynamis, vol. 25, (2005). p. 87-116. 
clinical and epidemiological study of the diseases that most affected the population of the city and province of Córdoba. ${ }^{18}$

Even so, specifically medical thinking about poliomyelitis in Córdoba has a relatively short history. Papers on the subject published by local doctors prior to 1943 are almost unknown. It hardly seems surprising that the study of poliomyelitis received a limited amount of attention, since the disease affected relatively few patients. Between 1943 and the epidemic that took place in Cruz del Eje in 1946-1947, only seventy cases were reported each year. The number of patients affected rose to just 164 during the epidemic of 19511952, according to research carried out by Luis Alberto Lezama, who was, at the time, a technical assistant in the traumatology and orthopedics department of the Universidad Nacional de Córdoba. ${ }^{19}$

If the small amount of cases reported per year might be considered one factor that could explain why so few articles on the disease were written, the connection between low mortality rates and a low level of research years leading up to 1953 seems stronger, particularly in terms of epidemiology. The following chart shows the number of polio deaths reported in the years between 1943 and 1952.

Figure 1: City of Córdoba. Polio mortality rate per 100,000 residents.

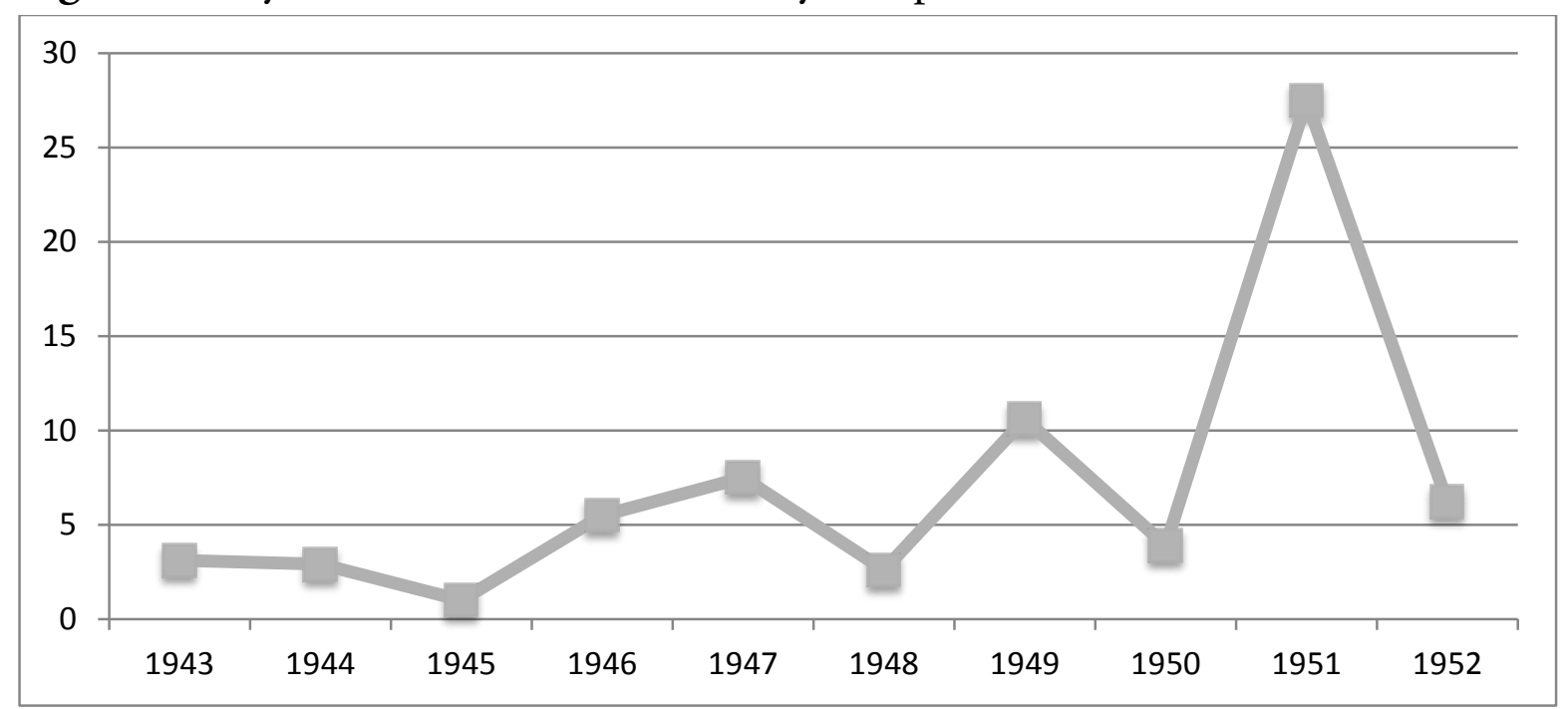

Source: In-house production based on: Lezama, Luis Alberto (1954): "La Parálisis infantil en la ciudad de Córdoba", Revista de la Facultad de Ciencias Médicas de la Universidad Nacional de Córdoba, Año XII, Julio-Septiembre Nro. 3, Córdoba, Argentina.

18 M.L.Rodriguez. "Perspectivas en torno a la consolidación de la elite médica de Córdoba. Epidemias y Estado, 1878-1923". Undergraduate thesis, Facultad de Historia, Universidad Nacional de Córdoba, (Córdoba, 2006). p. 35.

19 L.A. Lezama "La Parálisis infantil en la ciudad de Córdoba", Revista de la Facultad de Ciencias Médicas de la Universidad Nacional de Córdoba, Año XII, JulioSeptiembre Nro. 3, (Córdoba, 1954).p.302. 
In 1944, Guillermo Allende and Oscar Malvarez, two doctors associated with the Chair of Traumatology and Orthopedics, wrote an article that appeared in the Revista de la Facultad de Ciencias Médicas of the Universidad Nacional de Córdoba titled "Spinal Poliomyelitis (Heine-Meidin Disease)" which attempted to describe the symptomology and treatment of both the acute phase and the convalescence period of this disease. ${ }^{20}$ In general terms, we might consider these studies to be another product of Argentina's concern about the increase in its polio-related deaths, which totaled 2,280 in 1942 and 1943. ${ }^{21}$ Though the authors "display an understanding" of the concerns that infantile paralysis had generated among the public, they were also forthright about their doubts that both their countries and their region's leading doctors had about the ability of prophylactic measures to prevent infection and break the chain of contagion. Still, despite acknowledging the public's concern with polio and its prophylaxis, the article sidesteps the impact that the disease had had on the city and province of Córdoba and on Argentina in general, even though mortality statistics that described the disease's effects were available for all of these jurisdictions. ${ }^{22}$ Instead, it describes research that had been carried out in the United States, and, especially, Sweden. It describes a number of existing orthopedic treatments and refers to the "treatment of known aftereffects" and the "correction of deformities" without alluding to what treatment technologies might have been available in Córdoba or to the work that had been done in this field by local pediatricians or by specialists at the province's own school of medicine. ${ }^{23}$

Similarly, when considering questions of etiology and epidemiology, the article seems to depend entirely on research carried out in first-world nations,

20 L.A. Lezama "La Parálisis infantil en la ciudad de Córdoba", Revista de la Facultad de Ciencias Médicas de la Universidad Nacional de Córdoba, Año XII, JulioSeptiembre Nro. 3, (Córdoba, 1954). p. 302.

21 K. Ramaciotti. Las politicas sanitarias del primer peronismo: ideas, tensiones y prácticas. Thesis defended at the Facultad de Ciencias Sociales de la Universidad de Buenos Aires, (Buenos Aires, 2008). p. 203.

22 Although the articles analysed do not use statistical data, statistical production has been always an activity conducted by the Province. At least since the beginning of the twentieth century there were various Statistical Yearbooks of the Province made by the governments of these years. According to the documents consulted, this activity developed by the Department of Statistics did not stop between 1943 and the early peronist years. In 1952 the Secretary of Statistics and Census was created by law as part of the Ministry of Finance, Economy and Social Welfare with an effort to rationally centralize" (...) the implementing of statistical service of the Province". Collection of Laws of the Legislature of the Province of Córdoba, 1952, Volume 32, p. 113.

23 G. Allende, Guillermo and O. Malvarez. "Poliomielitis anterior", Revista de la Facultad de Ciencias Médicas de la Universidad Nacional de Córdoba, Año I, Marzo, Nro. 1, (1944), p. 4. 
most notably the United States. This goes beyond mere reference: the article seems to be a perfect reproduction of knowledge produced elsewhere and lacks even a single mention of any clinical or statistical data. In etiological terms, it is clear that the authors have made the doubts expressed by foreign researchers their own. When discussing the progress of poliomyelitis as it relates to age, the authors "observe" that the disease is most fatal to patients between one and five years old, though this statement is not backed up by any analyses made locally or, for that matter, in any part of Argentina. They go on to assert that the incidence of the disease is increasing in older children, though they neither provide any locally sourced information about polio's prevalence in this age group nor provide an explanation for this trend based on observations of epidemiologically significant behaviors. When discussing the disease's epidemiology, they limit themselves to reproducing conjectures made by American doctors, such as "the fact that the clear majority of polio patients belong to this age group leads us to suspect a late acquisition of a spontaneous and endogenous immunity brought about by growth and perhaps by hormonal factors of a sexual nature." They cite a similar cause when explaining why males predominate in polio's patient group. ${ }^{24}$

The section that discusses factors that contribute to the development of polio's acute phase perhaps best demonstrates the privileged place that scientific studies originating from economically dominant countries occupy in this article. Since doctors in the United States had emphasized the significance of muscle fatigue and chills as contributing factors, the authors do, too. They illustrate this point by describing the treatment of "a beautiful twelve-year-old girl who had recently undertaken a vigorous gymnastics program in preparation for a dance class and had bathed in a public pool the day before she suffered her attack." ${ }^{25}$

A review of the authors' research methods also suggests that they ignored their own experiences or any variables introduced by the local epidemiological environment. They avoid discussing or questioning why the number of polio cases in Córdoba had increased, sketching out an ambiguous argument by claiming that it was "logical to suppose, looking back to when cases were sporadic, compared to the more recent epidemics, that the germ has grown progressively more virulent or that the human organism has lost its immunity

24 Allende, Guillermo and O. Malvarez. "Poliomielitis anterior", Revista de la Facultad de Ciencias Médicas de la Universidad Nacional de Córdoba, Año I, Marzo, Nro. 1, (1944), p. 6.

25 Allende, Guillermo and O. Malvarez. "Poliomielitis anterior", Revista de la Facultad de Ciencias Médicas de la Universidad Nacional de Córdoba, Año I, Marzo, Nro. 1, (1944), p. 6. 
against it." ${ }^{26}$ Of course, the authors neither conceptualize nor discuss the term "epidemic" and refer instead to American or European cases. In these places, however, polio was not discussed as a global phenomenon.

These authors employed similar types of strategies when they considered the way in which the virus spread. In a later paragraph, they link contagion with healthy carriers and ask if these individuals spread the disease directly or through some other vector. When considering this question, they refer only to studies carried out at Yale University which had succeeded in infecting monkeys using the papillae of flies taken from epidemic-stricken areas and in isolating the virus on the feet of flies and mosquitos. ${ }^{27}$ As for the nosology and epidemiology of polio's spread, they write that, "current thinking leads us to believe that the virus passes directly from the sick to the healthy. In a small number of cases, the fly acts as the principal intermediary: it carries the sick individual's virus from his feces or waste, or from contaminated water, and infects another individual, either through direct contact or through the contamination of water, milk, vegetables, etc." ${ }^{28}$ However, despite this battery of conjectures, the authors do not venture to make any recommendations about prophylaxis: "We must note, unfortunately, that we do not possess the necessary means with which to effect a successful prophylaxis, since the virus's point of entry remains unknown and we cannot determine which children are most susceptible to contagion by this disease. ${ }^{29}$

Another fundamental aspect of poliomyelitis emphasized by doctors of the time was the connection between social class and the incidence of infantile paralysis. It was originally believed that this disease affected wealthier populations and that the children of the poor were immune. Two professors who taught at the Facultad de Ciencias Médicas of the Universidad Nacional de Córdoba, Dr. González Alvarez and Pedro Luque, expanded upon this theme in an article they published in 1946 that they titled "Epidemiology and

26 Allende, Guillermo and O. Malvarez. "Poliomielitis anterior", Revista de la Facultad de Ciencias Médicas de la Universidad Nacional de Córdoba, Año I, Marzo, Nro. 1, (1944), p. 7.

27 Allende, Guillermo and O. Malvarez. "Poliomielitis anterior", Revista de la Facultad de Ciencias Médicas de la Universidad Nacional de Córdoba, Año I, Marzo, Nro. 1, (1944), p. 7.

28 Allende, Guillermo and O. Malvarez. "Poliomielitis anterior", Revista de la Facultad de Ciencias Médicas de la Universidad Nacional de Córdoba, Año I, Marzo, Nro. 1, (1944), p. 8.

29 Allende, Guillermo and O. Malvarez. "Poliomielitis anterior", Revista de la Facultad de Ciencias Médicas de la Universidad Nacional de Córdoba, Año I, Marzo, Nro. 1, (1944), p. 8. 
Prophylaxis in Heine-Medin Disease." ${ }^{30}$ Despite its title, the authors of this article, like the authors of the one that was discussed previously, based their work on a series of studies that had been carried out abroad. The scientists they chose to discuss were again American or European, and often Swedish. In this case, the authors accepted as valid the conclusions drawn by epidemiological studies carried out by Lyon, Huntington, and Price, who had drawn nosological maps for the disease that showed that poliomyelitis was found predominantly in poor areas that lacked facilities for personal and public hygiene and in which flies were abundant. ${ }^{31}$ The article did not even mention the existence of the city of Córdoba or its social organization, though it did advance certain criticisms that grew out of preconceived notions about the inadequate hygienic habits of the working classes. It recommended the hospitalization of working-class children because it would allow doctors to study them in isolation, since "when it comes to children who come from working-class backgrounds, this step will allow them to receive therapeutic treatment, which might be decisive in the outcome of their cases. ${ }^{{ }^{3} 2}$

\section{Poliomyelitis in the City of Córdoba: Toward an Affirmation of the Local}

It might have taken a minor polio epidemic in 1949 and 1950 and another, more serious, epidemic in 1951 and 1952 to convince Córdoba's scientists to begin epidemiological studies whose research drew on both knowledge about poliomyelitis that originated in better-developed countries and from their own experience of Córdoba's situation. To this end, the Revista de la Facultad de Ciencias Médicas published a very interesting article by Dr. Luis Lezama titled "Infant Paralysis in the City of Córdoba" in 1953.

The level of epidemiological specificity that this article displays suggests a clear break from earlier works, which were clearly bibliographical in nature or were merely intended to systematize or recapitulate global findings about the disease. In contrast, this article uses local variables to explain the distribution

30 F.González Alvarez y P. Luque. "Epidemiología y Profiaxis de la enfermedad Heine Medin", Revista de la Facultad de Ciencias Médicas de la Universidad Nacional de Córdoba, Año III, Octubre-Diciembre Nro. 4, (1946), p. 27.

31 F.González Alvarez y P. Luque. "Epidemiología y Profiaxis de la enfermedad Heine Medin", Revista de la Facultad de Ciencias Médicas de la Universidad Nacional de Córdoba, Año III, Octubre-Diciembre Nro. 4, (1946), p. 27.

32 F.González Alvarez y P. Luque. "Epidemiología y Profiaxis de la enfermedad Heine Medin", Revista de la Facultad de Ciencias Médicas de la Universidad Nacional de Córdoba, Año III, Octubre-Diciembre Nro. 4, (1946), p. 37. 
of polio cases in Córdoba and the incidence of the disease among different social classes. It is even possible to argue, as we will, that this article went further: it moved an ongoing discussion about public sanitation, which had been a central issue for Argentina's doctors and politicians during that era, to center stage.

First of all, Dr. Lezama's article, which is based on clinical histories, is an excellent epidemiological study which breaks down poliomyelitis cases in the city of Córdoba by age and sex. In contrast with the aforementioned studies, the author uses these variables to develop an analysis in which he compares the information he collected with the experiences of doctors in other cities, such as Havana, Cuba, and in places like Florida and Connecticut. ${ }^{33}$

It is even more interesting to note that the doctor from Córdoba who wrote this article found important differences between what had taken place in Córdoba and what took place in these other locales. He determined, for example, that the children affected by poliomyelitis in Córdoba were, on average, younger than the children who had been affected by the disease elsewhere. Similarly, Dr. Lezama used the clinical histories of fifty local patients to reconstruct the symptoms they experienced during the epidemic of 1951-1952..$^{34}$ He used this information to develop a strikingly original analysis of the epidemiology of polio in the city of Córdoba. Specifically, working from the theory of oral and not aerosol contagion - a controversy which had already been discussed in other works, and particularly in the ones profiled above - the author drew a connection between the city's polio cases and the extent of its sewer and potable water services. His research was accompanied by maps that drew on his own research to illustrate the distribution of polio cases throughout the city and the city's own municipal maps, which illustrated the geographic extent of its sanitary services. ${ }^{35}$ Dr. Lezama reached the following conclusion: "A higher rate of mortality is observed in zones that lack sewers and whose housing is served by cesspits, as can be observed in the city's

33 L.A. Lezama "La Parálisis infantil en la ciudad de Córdoba", Revista de la Facultad de Ciencias Médicas de la Universidad Nacional de Córdoba, Año XII, JulioSeptiembre Nro. 3, (1954). p. 293.

34. A. Lezama "La Parálisis infantil en la ciudad de Córdoba", Revista de la Facultad de Ciencias Médicas de la Universidad Nacional de Córdoba, Año XII, Julio-Septiembre Nro. 3, (1954). p. 293.

35. A. Lezama "La Parálisis infantil en la ciudad de Córdoba", Revista de la Facultad de Ciencias Médicas de la Universidad Nacional de Córdoba, Año XII, Julio-Septiembre Nro. 3, (1954). p. 293. 
Map 1: Distribution of polio cases throughout the city of Córdoba's sanitary services

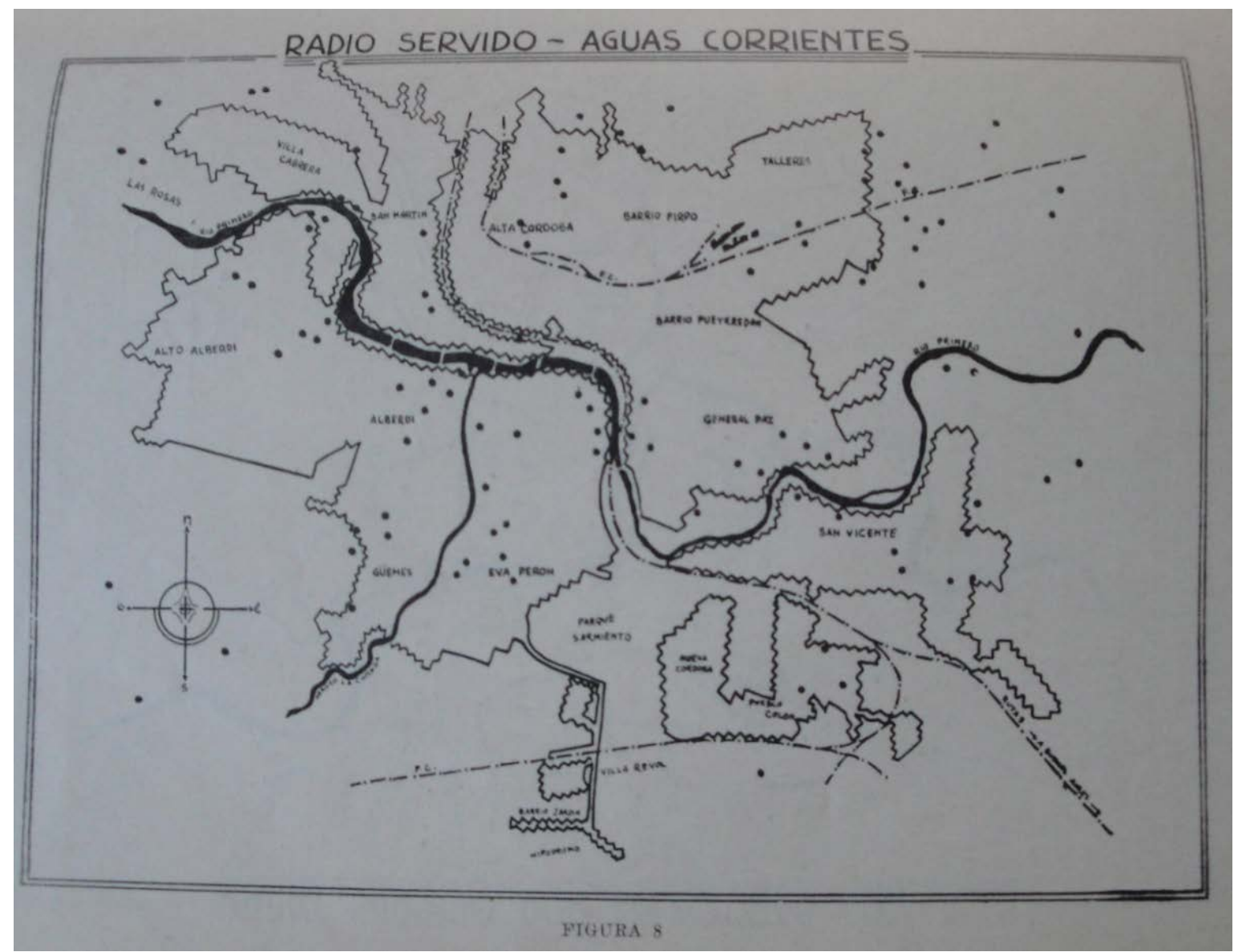

Source: Photograph of the map made by Dr. Lezama, Luis Alberto (1954): "La Parálisis infantil en la ciudad de Córdoba", Revista de la Facultad de Ciencias Médicas de la Universidad Nacional de Córdoba, Año XII, Julio-Septiembre Nro. 3, Córdoba, Argentina.

eastern and southeastern neighborhoods, which are densely populated areas that lack sewers." 36

When this article's findings are considered using its own investigative standards, we find that its own research does not establish a connection between the availability of potable water and polio cases in the city of Córdoba. We should note, however, that the doctor who compiled this report did so using clinical histories belonging to the Traumatology and Orthopedics department of the Hospital de Niños, which worked in cooperation with the Universidad Nacional de Córdoba's nursing school, its Kinesiology and Rehabilitation department, and the chairs of Traumatology and Orthopedics

36 Lezama, Luis Alberto (1954): "La Parálisis infantil en la ciudad de Córdoba", Revista de la Facultad de Ciencias Médicas de la Universidad Nacional de Córdoba, Año XII, Julio-Septiembre Nro. 3, Córdoba, Argentina, pp. 301-302. 
Map 2: Incidences of polio with the distribution of running water and sewage services in the city of Córdoba

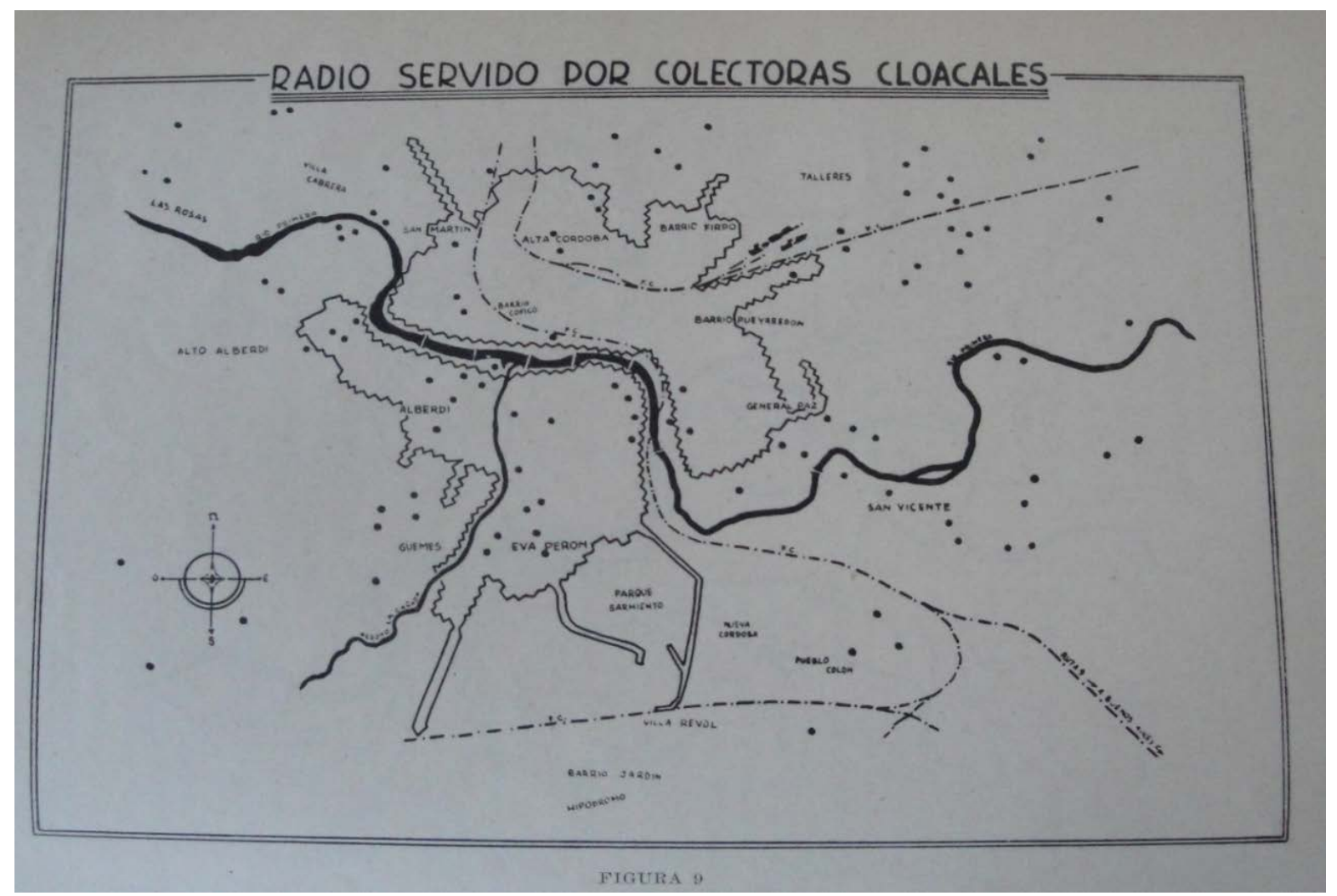

Source: Photograph of the map elaborated by Dr. Lezama, Luis Alberto (1954): "La Parálisis infantil en la ciudad de Córdoba", Revista de la Facultad de Ciencias Médicas de

attached to its medical school. In 1953, the Hospital de Niños was the only institution equipped with these resources in Argentina's north and northcentral regions and so received poliomyelitis patients from a very significant portion of Argentina's territory. However, the author's decision to relate incidences of polio with the distribution of running water and sewage services in the city of Córdoba attempted to remedy a potentially distortive aspect of the disease's mortality statistics by discounting cases that originated in the country's other regions. ${ }^{37}$

While this article presented an exhaustive year-by-year analysis of poliorelated deaths in the city of Córdoba from 1943 to 1952, it followed the lead of various hypotheses posited by American scientists and considered the ages at which patients in Córdoba had been affected by the disease, their races, the socioeconomic profile of the disease, and the area's sanitary conditions. While we cannot definitively claim that this sort of research might have constituted part of an independent effort to increase the sum total of knowledge related to

37 A. Lezama "La Parálisis infantil en la ciudad de Córdoba", Revista de la Facultad de Ciencias Médicas de la Universidad Nacional de Córdoba, Año XII, Julio-Septiembre Nro. 3, (1954). p. 310. 
poliomyelitis, the question of whether this investigation constitutes the beginning of an autochthonous scientific culture remains open.

While the influence of European medical science on Argentina's medical sciences $^{38}$ and on the medical science developed in Córdoba is undeniable, and the processes of knowledge appropriation that can be seen to occur in Dr. Lezama's article make reference to scientific advancements made elsewhere. However, the article also puts local processes of reception and resignification into play. In this sense, we would argue both what is appropriated, in terms of knowledge, and the process of appropriation itself should be considered part of a dynamic process that mediates between information's initial reception and its subsequent diffusion in the local community.

Doctors, in effect, set a certain threshold that defined the epidemiology of infantile paralysis not in terms of any internationally recognized body of knowledge about poliomyelitis but in terms of the concepts and notions that shaped Argentina's thinking about the condition. From a medical point of view, the events that took place in Córdoba in 1951-2 were comparable to events that had occurred in New York in 1944, London in 1947, and in Berlin. If one uses the term as it was understood by the international standards that governed treatment of the disease, they constituted an epidemic.

The article under discussion analyzed data from the city of Córdoba and attempted to understand and analyze cases of poliomyelitis as they related to a number of factors. It then used information gleaned about these cases to raise awareness about the disease and to advocate for the declaration of a state of emergency. According to the standard that Dr. Lezama employed, an epidemic was thought to exist when the amount of cases recorded rose above the level of twenty per hundred thousand inhabitants: by 1951, the rate of infection was seven percent higher than what was considered epidemic level. ${ }^{39}$

During those years, such a declaration was no minor matter. The same year that Dr. Lezama's article was published, the state organism in charge of Argentina's hygienic standards, which was quite aware of the increase in the county's polio cases, referred to them as part of a "global epidemic wave." The government, however, was so determined remain uninvolved that at a press conference held on April $2^{\text {nd }}, 1953$, Argentina's health minister - going against the health standards used by Dr. Lezama - underlined his contention that the cases of poliomyelitis that had been reported in Córdoba did not

38 J. Buschini. "Una carrera profesional con espacio para la ciencia en la Argentina de la primera mitad del siglo XX: Ángel Roffo y la cancerología experimental”, Quipu, vol. 14, núm. 2, (2012). pp. 267-293.

39 A. Lezama "La Parálisis infantil en la ciudad de Córdoba", Revista de la Facultad de Ciencias Médicas de la Universidad Nacional de Córdoba, Año XII, Julio-Septiembre Nro. 3, (1954). p 305. 
constitute an epidemic, since the rate did not reach one case per every ten thousand inhabitants. ${ }^{40}$ As has often happened throughout the history of Argentine public health, the "public's psychosis" was blamed on doctors who, armed with uncertain estimates, facilitated the spreading of "unfounded rumors." ${ }^{\prime 11}$ Of course, in this case, it was an Argentine doctor who was responding to a health issue with well-founded scientific arguments, made after conducting an investigation that sought to engage with both local perspectives and knowledge produced abroad. The doctor in question was also arguing that poliomyelitis was not just a medical problem, but, in the context of increasing mortality, a political one.

\section{Conclusions}

Our article is only an initial approach to the issues surrounding the accumulated knowledge about poliomyelitis's nosology and epidemiology as they relate to a series of events that took place in Argentina's interior. Still, we believe it provides an opening into a number of questions that deserve more thorough investigation. The most significant of these questions refers to the complex interactions that took place between science and politics and between internationally recognized scientists and those native to Argentina and to Córdoba. It also calls into question the decisions taken and the viewpoints assumed by an exclusive medical elite that, even today, has succeeded in establishing a cognitive monopoly that successfully resists the pressures exerted upon it by both society and confers upon itself an air of legitimacy in the eyes of its fellow professionals.

Scientific logic itself leads us to conclude that the esteem with which the articles analyzed above that date from 1944 and 1946 viewed scientific developments made in Europe and North America refer to power dynamics and the transmission of knowledge from powerful countries to so-called peripheral jurisdictions. This article does not engage these questions directly, but, when considering these dynamics, it should be understood that scientific knowledge is not necessarily universal in character: it is produced through

40 K. Ramaciotti. Las politicas sanitarias del primer peronismo: ideas, tensiones y prácticas. Thesis defended at the Facultad de Ciencias Sociales de la Universidad de Buenos Aires, (Buenos Aires, 2008). p. 203.

41 K. Ramaciotti. Las politicas sanitarias del primer peronismo: ideas, tensiones y prácticas. Thesis defended at the Facultad de Ciencias Sociales de la Universidad de Buenos Aires, (Buenos Aires, 2008). p. 203. 
local means, and it "universalization" is largely a project of power. ${ }^{42}$ The relatively brief period of time that elapsed between the publishing of the articles examined in this report - two of which were published in the nineteen forties, and the last of which was published in 1953 - should remind us of the importance of investigating the local social variables particular to each environment. We have attempted in this article to show that one need not always search for a political shift to explain the differences that appear between one historical moment and another. Rather, we believe that it could be argued that we have observed a shift in the agenda of Córdoba's leading doctors, who would later show themselves to be more receptive to poliomyelitis research as the city's number of poliomyelitis cases rose. At first, Córdoba's leading doctors barely seemed to recognize poliomyelitis as an investigative priority. They were later to reject this view and to join and investigative tradition that was then being developed in the province, one that was based in local epidemiological concerns. While their work did not contradict the universal practices or cognitive models that were being constructed and diffused at this time, the new spaces that were opened up after the polio outbreaks of 1949-1950 and 1951-2 seem to have been ideal environments for the construction of scientific research practices informed by both an international body of knowledge about poliomyelitis and by issues relevant to the city of Córdoba.

As we have previously suggested, we believe that the path taken by medicine as it developed in Córdoba both caused notable disruptions the medical field in regards to the treatment of polio and questioned the legitimacy of larger, politically hegemonic structures. The exploratory character of this article implies limitations: these did not permit us to deepen our study of the dynamics we have described here. This article has, however, enabled us to highlight some historical evidence and make some general conjectures that allow for a deeper understanding of Córdoba's experience and the complex relationships that create tension, not only on the local level, but also in national and perhaps even international contexts. In our opinion, it is important to carefully examine the way that these relationships are understood in both epidemiological and power-oriented political contexts.

Dr. Adrián Carbonetti is associate professor of the "Centro de Estudios Avanzados", National University of Córdoba. Main Researcher at the "Consejo Nacional de Investigaciones Científicas y Técnicas" in Argentina.

42 D. Hurtado de Mendoza. La Ciencia Argentina. Un proyecto inconcluso: 19302000, Edhasa, (Buenos Aires, 2010). p. 23. 
Dr. Lila Aizenberg is post-doctoral fellow at the "Consejo Nacional de Investigaciones Científicas y Técnicas" in Argentina.

Dr. Maria Laura Rodríguez is assistant professor of the History Department, National University of Córdoba. Research Assistant at the "Consejo Nacional de Investigaciones Científicas y Técnicas" in Argentina. 


\section{References}

Allende, G. and Malvarez, O., "Poliomielitis anterior", Revista de la Facultad de Ciencias Médicas de la Universidad Nacional de Córdoba, Año I, Marzo, Nro. 1, (Córdoba, 1944).

Ansaldi, W., Industria y urbanización, Córdoba, 1880-1913, Universidad Nacional de Córdoba, Mimeo, Tesis Doctoral, (Córdoba, 1977).

Arce, H., El territorio de las decisiones sanitarias, Ed. H. Macchi, (Buenos Aires, 1993).

Armus, D., "Los médicos, profesiones, poder y prestigio", Cuadernos de Historia, Popular Argentina, CEAL, (Buenos Aires, 1981).

Buschini, J., "Una carrera profesional con espacio para la ciencia en la Argentina de la primera mitad del siglo XX: Ángel Roffo y la cancerología experimental”, en Quipu, vol. 14, núm. 2, (2012).

Canguilhen, G., "O Objeto da Historia das Ciencias, in: Carrilho, M M (org.) Epistemologia: posiçones e críticas, Fundaçao Gulbenkian. (Lisboa: 1991).

Carbonetti, A., "El sistema sanitario en la provincia de Córdoba, 1880-1926", Dynamis, vol. 25, (2005).

Capponi, S., "Epistomologia, historia de las ciencias y saber médico", Episteme, v. 11, Nro. 23. (2006)

Collection of Laws of the Legislature of the Province of Córdoba, 1952

Dadone, A., "Cien de la industrialización en Córdoba 1873-1973", Revista de Economía Banco de la provincia de Córdoba, $\mathrm{n}{ }^{\circ}$ 24, (Córdoba 1974).

Ferrante, P., "Rengueando el estigma: Modos de ser, pensar y sentir (se) dispacitado construidos desde la práctica deportiva adaptada", RBSE, 9(27), (2010).

González Alvarez, F., and Luque, P., "Epidemiología y Profiaxis de la enfermedad Heine Medin", Revista de la Facultad de Ciencias Médicas de la Universidad Nacional de Córdoba, Año III, Octubre-Diciembre Nro. 4, (Córdoba, 1946).

Hurtado de Mendoza, D., La Ciencia Argentina. Un proyecto inconcluso: 19302000, Edhasa. (Buenos Aires, 2010)

Quintero Toro, C., “¿En qué anda la historia de la ciencia y el imperialismo? Saberes locales, dinámicas coloniales y el papel de los Estados Unidos en la ciencia en el siglo XX", Historia Crítica, Nro. 31, (2006).

Koyre, A., Estudios de historia del pensamiento cientifico, Editorial Siglo Veintiuno, (México, 1982).

Lezama, L.A., "La Parálisis infantil en la ciudad de Córdoba", Revista de la Facultad de Ciencias Médicas de la Universidad Nacional de Córdoba, Año XII, Julio-Septiembre Nro. 3, (Córdoba, 1954). 
Rodriguez, M.L., Perspectivas en torno a la consolidación de la elite médica de Córdoba. Epidemias y Estado, 1878-1923. Tesis de Licenciatura en Historia. Universidad Nacional de Córdoba, (Córdoba, 2006).

Rodriguez M.L., La medicalización de la ciudad de Córdoba en tiempos epidémicos: conceptos, saberes e intervenciones 1878-1927. Editorial de la Municipalidad de Córdoba. (Córdoba, 2011),

Ramaciotti, K., Las politicas sanitarias del primer peronismo: ideas, tensiones y prácticas. Tesis defendida en la Facultad de Ciencias Sociales de la Universidad de Buenos Aires. (Buenos Aires, 2008),

Report of the Dirección General de Estadística Censos e Investigación, Ministerio de Hacienda, Economía y Previsión Social de la Provincia de Córdoba, 1944-1948. Published in 1953.

Report of the Direccion General de Estadistica Censos e Investigación, Ministerio de Hacienda, Economía y Previsión Social de la Provincia de Córdoba, 1949-1951. Published in 1953.

Rosenberg, C., "Disease in History: Frames and Framers, The Milkbank Quarterly, 67, Suppl. 1. (1989).

Testa, D., "Poliomielitis: la "herencia maldita" y la esperanza de la rehabilitación. La epidemia de 1956 en la Ciudad de Buenos Aires. Intersticios, Vol. 5 (2). (2011).

Vessuri, H., "El crecimiento de una comunidad científica en argentina", Cad.Hist.Fil.Ci., Campinas; Serie 3, V 5, Nro. Especial. (1995) 